\title{
DE KLEEDING DER SURINAAMSCHE BEVOLKINGS- GROEPEN IN VERBAND MET AARD EN GEWOONTEN DOOR
}

TH. VAN LELYVELD

(Vervolg).

\section{De Neger.}

Waar bij de neger- en kleurlingvrouw uit het volk ijdelheid en coquetterie, die zij in zulk een hooge mate bezitten, hebben geleid tot het ontstaan van een zeer oorspronkelijke kleeding, waaraan uitermate zorg wordt besteed, kenmerkt zich de kleeding van den neger en kleurling door absoluut gemis aan individueel karakter. Een nationale dracht, die de immigranten, wel hebben, houden zij er niet op na, doch een dergelijke volksdracht ontstaat alleen bij naties van ontwikkeling en beschaving, zooals de Javanen en Britsch-Indiërs. De negers zijn nooit een volk geweest van cultuur; in hun vaderland leefden zij als primitieve natuurmenschen en zij vonden het dus niet noodig om het lichaam meer te bedekken dan het welvoegelijkheidsinstinct vereischte.

Intusschen bedenke men wel, dat bij naakt loopende volken het welvoegelijkheidsbegrip groote verschillen vertoont met het onze. Een dier verschillen kan duidelijk worden uit het volgende : in den slaventijd had een in de stad wonende dame een negerjongen van een jaar of I4 als voetebooi van de plantage meegenomen; deze die altijd naakt geloopen had, behalve dan zijn lendedoek, werd netjes aangekleed in linnen broek en jasje. Toen hij evenwel den eersten keer, alzoo uitgedost, door zijn meesteres geroepen werd, verscheen hij niet en hij was ook nergens te vinden. Eindelijk trof men hem verscholen achter een deur en op de vraag waarom hij niet gehoorzaamd had, toen hij bij herhaling geroepen werd, antwoordde hij bedremmeld : „Ik ben beschaamd omdat ik een broek aan heb”. („,Mi sjin, mi weri broekoe").

Dit beschamend gevoel moet, in een dergelijk geval, wel ieder wezen krijgen, dat buiten eenige gemeenschap met den 
Europeaan, zich te midden van zijn ook naakte stamgenooten, altijd frank en vrij bewogen heeft zooals de natuur hem ter wereld heeft gebracht. Raakt ditzelfde individu echter gewend aan den omgang met aangekleede menschen en zijn deze bovendien zijn meesters, dan groeit de zucht - en die is bij de negers sterk - om die meesters zooveel mogelijk, zij het in uiterlijkheden, nabij te komen. Want twee dingen zijn er die de neger den Westerling altijd benijd heeft, vooreerst diens blanke huidkleur en ten tweede zijn kleeding. Het eerste te bereiken is hem onmogelijk, doch hij meent den Euroepeaan toch eenigermate te evenaren, wanneer hij zich niet naakt aan hem vertoont, maar evenals hij zelf in jas en broek. In den slaventijd openbaarde zich dit duidelijk en de zucht naar genoegens en mooie kleeding gaf, door te geringe bijverdienste of het ontbreken daarvan, aanleiding tot tallooze diefstallen.

Pogingen om in dien tijd luxe-neigingen bij den neger tegen te gaan, baatten niet en buitendien had daar de plaatselijke handel zeer op tegen. Er was geen sprake van om de ingewortelde ijdelheid, die zich voornamelijk uitsprak in het dragen van kleeren, ook maar eenigszins te fnuiken.

Zeer vermakelijk werd die neiging door Benoit geillustreerd in zijn hier voren vermeld werk; een naakte neger wordt door een slaaf-kleermaker aan diens open straatdeur de maat genomen, opdat alle voorbijgangers zouden kunnen zien, dat hij zich in de kleeren ging zetten (plaat r6).

Bij het nader bekijken van Benoit's teekeningen, valt op te merken, dat de bastiaans of neger-officieren op de plantages in tegenstelling van de blank-officieren - die belast waren met het toezicht op de slavenmacht en den arbeid der negers, gekleed gingen in buis met broek, of met een lange jas met broek, (plaat I7), terwijl de slaven en de tentbootroeiers der plantages meestal de lenden slechts bedekten met een doek. Dikwijls werd ook een kort wit of gekleurd broekje gedragen, en dit was eigenlijk de algemeene dracht van alle slaven in de stad, de karrevoerders, lastdragers, enz. Men zag ook wel buisjes zonder mouwen, om den rug te beschermen tegen de zengende zonnestralen; de lenden werden door een doek omgord, doch velen vonden een lapje voor het schaamdeel al voldoende.

Was de hoofddoek bij de mannen, zooals bij vele Aziatische volken, niet in zwang, en moesten dus de dikwijls zware vrachten 
direkt op het dikke kroeshaar worden getorst, toch blijkt uit een van Benoit's platen dat de in het wit gekleede volgers achter een begrafenis van een welgesteld Europeaan, het hoofd dekten met een witten hoofddoek. Zeer opmerkelijk is overigens bedoelde teekening (plaat 2) om de wijze waarop toen ter tijd zoo'n personage naar zijn laatste rustplaats werd gebracht; de kist werd gedragen door I2 negers in witte jas en broek en deftig met een soort hoogen hoed op; daarachter volgden de heeren familieleden en bekenden in zwarten rok, terwijl het gelaat op zeer eigenaardige wijze afgedekt werd door een lange, breede klep vóóraan den hoed, waardoor het kijken, evenals in onze rouwkoetsen door de neergelaten gordijntjes, belemmerd werd. Achter den hoed hingen lange crêpe banden af, die door een slaaf in de hand werden gehouden, terwijl de andere hand den meester met een zonnescherm beschutte voor de zon.

Gold het feestdagen, een danspartij of een huwelijk, dan vergat de negerslaaf de kwellingen van den arbeid, hij was dan meer de meneer die 't er van nemen ging en hij voelde zich ook werkelijk als zoodanig, zoodra hij de begeerlijke jas en broek had"aangetrokken.

De huwelijksceremonie was al heel eenvoudig: de verliefde neger begaf zich naar den eigenaar van zijn uitverkorene, zette in haar bijzijn zijn trouwplan uiteen en beloofde goed voor zijn vrouw te zullen zorgen; de bruid gaf hem daarop een hand, en daarmee was de huwelijksvoltrekking afgeloopen. Huwelijken werden echter zooveel mogelijk in de hand gewerkt, omdat de kinderen eigendom werden van den eigenaar der moeder, die meestal dan ook zoo gul was om het huwelijk te doen vieren met een "'doe" of danspartij op de plantage. De gasten takelden zich dikwijls op deze festijnen, waar door het draaiend gedans al de bonte kleuren kaleidoscopisch dooreenwarrelden, op de meest zotte manieren toe ; men stak papegaaienveeren in het dichte kroeshaar, men wond zich op, aangewakkerd door het gedoeng-doeng der negermuziek en door het naar binnen werken van heel veel dram, d.i. de rum die uit melasse verkregen wordt. Den ganschen nacht was men in de meest dolzinnige uitgelatenheid, tierend en dansend met de door wijn of slechte likeuren eveneens benevelde vrouwen. Geroosterde bananen bevredigden den honger, maar de zoute bakkeljauw (gedroogde visch; van het Spaansche bacallao) die daartusschen door ver- 
orberd werd, prikkelde weer tot drinken. Het leed werd vergeten, de feestvierende slaaf voelde zich de gelukkigste aller menschen, maar tegen het aanbreken van den morgen, moest hij zijn door en door afgemat lichaam weer beschikbaar stellen voor den komenden arbeid.

In tegenstelling met deze doe's, werd door plechtige dansen het aandenken van overledenen herdacht. Kleedingstukken die anders nooit meer gedragen werden, genoten dan de eer weer te worden aangetrokken, wat aanleiding gaf tot wonderlijke combinaties en gehuld in zulk een toetakeling werd gebakken koek en geslacht op het graf der gestorvenen gebracht.

Ook waren dansen gebruikelijk die overleveringen waren van zeer oude gebruiken uit het vroeger vaderland en die in verband stonden met het geloof. Een Afrikaansche gewoonte was het om Zaterdags wanneer de maan scheen, te middernacht bij een kankantri - de hoogste, breedst vertakte en mooiste boom in Suriname - godsdienstige dansen uit te voeren, die Mama, Watermama, Winti, en Mapokora genoemd werden. De leider, een soort priester, was dan gekleed als Afrikaansch hoofdman, in de eene hand droeg hij een krom mes, in de andere een tak sangrafoe. Als hiermee de aanwezigen werden getikt, riepen zij : „Tata, tata. helpi mi”, d.w.z. God sta mij bij. Hard klapten zij daarop in de handen en onder luid schreeuwen en gillen, rolden en wrongen zij hun lichamen in allerlei kronkelingen en wendingen.

Niet minder rumoerig ging het toe bij den Ajaini en Iengiof tijgerofferdans, waarbij de priester zich bedekte met een wit kleed voorzien van tijgervlekken.

Zijn overgeërfd fetichisme leidde er toe, dat de negerslaaf zich over zijn toekomst of over onheilen niet bezorgd maakte en hij achtte zich voldoende tegen allerlei ongeluk beschermd door het dragen van amuletten of obia's die uit de meest vreemdsoortige snoeren bestonden of uit stukjes gesneden hout enz. Het leven nam hij dus vrij gemakkelijk op, vooral de stadsneger die in de Saramaccastraat - de Kalverstraat van Paramaribo - in allerlei drinkgelegenheden, onder gelach en vroolijk gezang met vrouwen en kameraden, het hardevanzijn dagelijksch bestaan vergat. Dat harde bestond echter voornamelijk in het gedwongen werken, want het meest afkeerig is de neger, die eigen bezigheden en inzonderheid het roeien, met vaak onver- 


\section{2}

moeiden ijver vervult, afkeerig van opgelegden en geregelden arbeid.

Zoodra de slaaf vrij was, trok hij schoenen aan, omdat dit hem vroeger verboden was; de swells onder hen vonden er een groot behagen in om zich zoo fraai mogelijk uit te dossen en prodo te maken tegenover elkander. De een droeg een gepande witte jas met neergeslagen kraag, waaronder een sterk kleurige das losjes werd gestrikt; de beenen staken in lange, opvallend wijde witte broek, een breede stroohoed dekte den bol en een parasol moest het teint beschutten tegen te felle zonnestralen. Een ander (plaat I9), verkoos een open, heel kort jasje, met verbazend hooge wijde boorden, waaronder de dasplooi viel, een wijde broek reikte tot de enkels; ook blijkt dat een geruite of een gekleurd buis boven een kuitbroek prachtig werd gevonden, en dat hoeden werden gedragen van de meest uiteenloopende modellen, soms zelfs met bonte veeren versierd.

Nog meer dan vroeger voelen de tegenwoordige negers, die den slaventijd nooit gekend hebben, zich als heeren der schepping als zij Zondags of op feestdagen zich zoo deftig kleeden in een tip-top westersch complet, bretels niet te vergeten. Het overdrevene in den snit legt echter altijd den poenigen kant bloot, vooral de wijde pantalon-éléphant, waaronder des te smaller de geschoeide voeten lijken. Ideaal is niet alleen het mooi glimmend verlakte schoeisel, maar dit is slechts dàn volmaakt, wanneer bij iederen stap door kraken en piepen, de aandacht daarop gevestigd wordt. Dat zware gouden kettingen, opzičhtige dasspelden, ringen en manchetknoopen van valsche steenen gretig gedragen worden, spreekt vanzelf; ook gouden pepite's (stukjes onverwerkt goud) aan de horlogeketting of op de das zijn zeer gezocht.

Uit een en ander openbaren zich enkele opmerkelijke trekken van den negeraard : in de kleeding bootst hij den Europeaan met voorliefde na. $\mathrm{Nu}$ is niet te ontkennen dat ook wij dit doen ten opzichte van b.v. Fransche en Engelsche modes, doch die modes zijn vindingen van menschen die tot ons zelfde ras behooren. Uit het feit echter dat een neger, die van een totaal verschillend ras is en leeft onder totaal andere klimatologische omstandigheden, geen kleeding draagt van een individueel karakter, vloeit voort, dat bij hem een eigen conceptie ontbreekt. Hij copieert, hij compileert en daarbij overdrijft hij gewoonlijk, 
door gemis aan fijnen smaak, door het gaarne aandacht op zich doen vestigen, door de kans dat hij, zich uiterlijk voordoende als een heer, ook behandeld zal worden met meer eerbied, een eigenschap die hij overigens gemeen heeft met onze minder ontwikkelde rasgenooten.

Het niet sobere, maar daarentegen opvallend overdrevene en drukke in zijn kleeding, is echter ook een reflex van zijn sterke neiging tot drukke praterij en 't is wel grappig dat hij, die zulk een onvermoeibare kakelaar is, dit verstandig spreekwoord er op na houdt: "mofto na soso, mara da fowloe meki sani" d.w.z. „kakelen geeft niets, als de hen maar eieren legt”, waarmee bedoeld wordt, dat het beter is niet te praten, maar wel te handelen.

Dit handelen beperkt de neger echter tot een minimum, zoodat hij zelden iets bereikt of tot een noemenswaard bezit geraakt, wat trouwens volgens hem, slechts lasten veroorzaakt en geestig door hem wordt uitgedrukt in het gezegde : „Hede krebi, a jrepi sesee”, d.i. „een kaal hoofd heett geen schaar noodig," m.a.w. hoe minder bezit, hoe minder zorgen.

Zorgen kent de neger dan ook niet; in een warm klimaat en in een land waar de rijke bodem zoo gul alles biedt wat de mensch noodig heeft om te kunnen leven, is de strijd om het bestaan niet groot. In zulke omstandigheden wordt des te gemakkelijker aan de ijdelheidszucht toegegeven, met het gevolg, dat de in Europeesche kleeding pronkende stadsneger zich ver verheven voelt boven zijn rasgenooten die langs de groote rivieren en in de wouden volkomen natuurmensch zijn gebleven.

\section{De Boschnegers.}

Het feit, dat er onder de slaven velen waren die de vlucht naar de onbekende binnenlanden verkozen boven de gehate, dagelijksche dwingelandij van den geregelden arbeid, toonde, dat juist deze vluchtelingen en wegloopers - de Marrons, van het Spaansche marro, d.i. ontsnappen - die zich in groote groepen in de wouden vereenigden, behoorden tot de meest energieken en dat dus de anderen van een minder zelfstandig en kordaat allooi waren.

Hun dorpen staan onder toezicht van een kapitein, bijgestaan door onder-kapiteins of "blaka djakti's”; de kapiteins 
met den granman als hoofdman vormen samen een raad of "lanti”, d.i. het land, het Gouvernement. Op de „kroetoe's” of vergaderingen van de lanti, neemt de granman plaats in een armstoel, vermoedelijk een overblijfsel van een gewoonte aan de Ivoorkust, door Clozel en Villamur gereleveerd : „La chaise royale ou la chaise du chef, qui joue un rôle essentiel dans tout le symbolisme politique des peuples 'Tchi, Aqui et Achanti". De kapiteins zitten op lage, gesneden bankjes; allen zijn dan gekleed in een kort hemd en met hun regeeringsstaf bij zich, n.1. een soort tamboer-majoorstok met grooten zilveren knop. Die van den granman was vroeger met blaren omwonden, later werd hij met koord omsnoerd.

De heeren van de lanti houden er bovendien eenstaatsiekleeding op na, waarin zij o.a. verschijnen op audienties of besprekingen met den Gouverneur der kolonie. Toch komt het zelden voor dat de granmans persoonlijk onderhandelingen komen voeren met het hoofd der kolonie, hoewel dit dikwijls noodig zou zijn.

Toen omstreeks 1895 het groot-opperhoofd King door de Saramaccaners was verkozen, kostte het zelfs veel moeite om hem naar de stad te doen komen ten einde door den Gouverneur te worden geïnstalleerd. Bij die gelegenheid verschenen King en zijn beide kapiteins in galacostuum voor den Gouverneur van Asch van Wijck en was het mij mogelijk het hooge gezelschap te fotografeeren.

Uit plaat 20 blijkt het ridicule van het waardigheidscostuum : King in een generaalsuniform van een oud régime, in de eene hand zijn omstrengelden gouvernementsstok, in de andere zijn ouderwetsche sabel; zijn beide adjudanten in gegallonneerde gekleede jas en hoogen hoed met oranje kokarde en alle drie versierd met een halve maanvormig zilveren halsschild, voorzien van het Nederlandsche wapen en waarvan de vorm denken doet aan de Javaansche sangsangan's, die o. a. evenzoo gedragen worden door bruiden en ook door grooten van het Javaansch tooneel.

Duidelijk spreekt uit een en ander de zucht om zich te spiegelen aan de kleeding en uniform der blanken; een hooge hoed en gekleede jas zijn deftig. maar de deftigheid wordt nog verhoogd door de gouden knoopen en gouden banden, terwijl de generaalsuniform de opperste kleedij was die men zich kiezen kon.

De bekende granman der Aucaners, wijlen Oseisie, hield er 
tevenseen zwartlakensch jaquette op na, waarbij hij een gestreepte pantalon droeg en schoenen natuurlijk. Zoo ontving hij in zijn residentie Drietabbetje, de borst gesierd met de zilveren medaille der Oranje-Nassauorde, de leden der Tapanahoni-expeditie op hoffelijke wijze. Oseisie was een groot heer en machtig hoofd die tucht te bewaren wist en er een rijksbestierder op nahield om zijn loopende zaken af te doen. Ten einde zijn gehechtheid te toonen aan het Nederlandsch gezag, gebruikte hij een zakdoek in de nationale kleuren. Het groot opperhoofd der Saramaccanerboschnegers Akroesoe, was in dat opzicht nog ostensiever, door het gebruik van een rood-wit-blauwe broek, met een oranjeband om de knie!

Fijne smaak en distinctie ontbreken den neger ten eenemale ; bekleedt hij een waardigheid, dan wil hij--evenals onze minder hoogstaande eerzuchtigen - gaarne beschouwd worden als een zeer gewichtig mensch, wien men grooten eerbied verschuldigd is, terwijl hij er tuk op is, dat door uiterlijke teekenen die waardigheid zoo duidelijk mogelijk naar voren komt. Dit blijkt o. a. ook uit het volgend voorval:

Toen ik indertijd den Gouverneur van Asch van Wijck vergezelde naar Albina, waar besprekingen met den granman Oseisie zouden worden gehouden, werden 's avonds laat, aan boord van het stoomschip Curaçao, de onderhandelingen besloten met den eisch van den granman om het recht te krijgen een oranje sjerp te dragen zooals hij mij zag aan hebben. Verklaard werd dat een dergelijke sjerp uitsluitend aan officieren kon worden toegekend, doch Oseisie nam daar geen genoegen mee, hij toch stond zoo oneindig veel hooger dan een nog jong luitenant, dat hij zijn verzoek niet onredelijk vond en daaraan bleef vasthouden. Tot zeer laat in den nacht werden deze, voor den granman zoo gewichtige besprekingen voortgezet, totdat de Gouverneur verzekerde de kwestie in beraad te zullen nemen en $\mathrm{ik}$ beloofde in zijn tegenwoordigheid de sjerp niet meer om te doen.

Wordt een boschnegerkamp door Europeanen bezocht, wat gewoonlijk door geweerschoten wordt gesignaleerd, dan is het ook beneden de waardigheid van den kapitein om zich geheel naakt aan hen te vertoonen. Is het bezoek onverwacht, dan rent hij fluks naar zijn hut om zich in de kleeren te zetten. Plaat 2I vertoont hem in een niet te fraaie jas en broek te mid- 
den van zijn dorpsgenooten aan de Maho-kreek (Saramacca); hij is dezelfde kapitein Jackson, die op de vorige plaat als adjudant fungeert van granman King.

Op plaat 22 verschijnt een andere kapitein van een kamp aan de Kromhoekoe-kreek (Saramacca), gedrapeerd in lange, kleurige manteljas en den kroeskop gedekt door een strooien matelothoed, terwijl de onderkapitein in zijn los hemd al een zeer poveren indruk maakt. Hoeveel natuurlijker, pretentieloozer, voor ons minder belachelijk en daarentegen prachtiger om te zien, zijn de andere, eenvoudige dorpelingen, wier athletische donker-naakte lichamen, glimmend in de zon, gelijken op bronzen statues van reuzenkrachtige oermenschen.

Het ligt voor de hand, dat de karaktereigenschappen van den neger grootendeels overeenkomen met die van den boschneger, omdat zij rasgenooten zijn. De natuurstaat echter, heett den laatste meer gevrijwaard van het overnemen der minder goede eigenschappen van den blanke en hem tevens in omstandigheden gebracht, waardoor hij minder makkelijk dan de stadsneger, in zijn levensonderhoud voorziet. Door jacht en visscherij moet hij een gedeelte van zijn voedsel zoeken en door tal van werkzaamheden, waarvoor geregeld veel van zijn spieren wordt gevergd, heeft de boschneger zijn oorspronkelijken, herculischen lichaamsbouw behouden, terwij1 de stadsneger is verslapt.

Zooals uit de platen 2 I en 22 duidelijk blijkt, is de boschnegerkleeding een zeer primitieve, maar ruim voldoende voor den in het wild levenden natuurmensch in een tropenland. De mannen gaan nagenoeg naakt; alleen wordt een lap gekleurd katoen, een kamisa (van het Portugeesch camisa of hemd) tusschen de beenen doorgehaald (plaat 22 en 23); achter-en vooreinden hangen af van een katoenband of kamisa-tétei d.i. kamisatouw, waaraan dikwijls de houwer gehangen wordt, die men altijd bij zich heeft en die gebruikt wordt als bijl of als mes. Soms ook slaan de mannen een bontgekleurden doek om het lijf, waarbij éen schouder vrij blijft, (plaat 2I).

In hun jeugd hebben de vrouwen, die zacht en vroolijk zijn van aard, buitengewoon mooie lichaamsvormen met een glanzende, zacht-satijnige huid, die evenwel een minder aangenaam aroma afgeeft. Zonder zoo coquette te zijn als de jonge negervrouwen uit de stad, is zij zich gewoonlijk wel bewust van haar ver- 
leidelijkheden en neemt zij ook gaarne complimentjes en aardigheden aan van haar stamgenooten. $\mathrm{Zij}$ is buitengewoon zindelijk van aard, zoowel op de kleeren als op het lichaam en evenals de mannen baadt zij zich elken dag in de rivier.

De meisjes, lenig en rank als jonge reeën, trouwen op zeer jeugdigen leeftijd; door het opeenvolgend krijgen van kinderen en door voortdurenden huis- en landarbeid, verliezen zij spoedig hun bekoorlijkheden. Zij loopen geheel naakt tot ongeveer dertienjarigen leeftijd, de tijd waarop een huwelijk kan worden gesloten. Daarna hangen zij een lap katoen om, kwejoe genaamd, of slaan evenals de gehuwden, een veelkleurigen, gestreepten of geruiten doek om de heupen en die paantje heet, van het Portugeesche panno, d.i. doek. Hoogstens wordt, als vreemdelingen in het kamp verschijnen, het négligé aangevuld door een schouderdoek of een jakje dat losjes om de borst gebonden wordt (plaat Io). Duidelijk openbaart zich een voorkeur voor groote, zeer eenvoudige patronen, uitgevoerd in sterke kleuren, zooals breede strepen, en groote ruiten of bladmotieven; dit wijst wel op den primitieven aanleg, doch deze forsche, decoratieve figuren, harmonieeren volkomen met den forschen lichaamsbouw en de diepdonkere huidkleur.

Hoewel vroeger, in den slaventijd, de vrouw in het kamp slechts gekleed was in haar paantje, maakte zij groot toilet wanneer bezoekers werden ontvangen of als zij haar man vergezelde naar naburige stammen, Een geplooide rok werd dan aangetrokken, een jak angedaan, een omslagdoek werd gebruikt, een hoofddoek gebonden en men versierde zich met armbanden, kettingen en oorringen, kortom; zij kleedde zich dan zooals de plantage- en stadsladies en verviel dus van het eene uiterste in het andere.

In dien tijd heerschte er trouwens, naast het primitieve leven van den natuurmensch, een grootere luxe bij de boschnegers dan tegenwoordig. Die luxe werd echter alleen tentoongesteld bij bezoek van vreemden, inzonderheid van blanken. Een tafellaken werd dan voor den dag gehaald, ook borden, schotels, vazen, enz. Meermalen werden bekleede fauteuils aangetroffen, die pronkten tusschen de witte boschnegerbankjes en zelfs gravures waren soms aan den wand gehecht. Een groot contrast vormde dit alles met de hangmat, en al het primitieve huisraad waartusschen eenden en kippen en biggen ongestoord prome- 
neerden. Hoe meer echter de boschneger weer terug keerde tot zijn wilden staat, hoe meer ook de Europeesche luxe-artikelen verdwenen en de vrouwen kleeden zich dan ook nimmer meer op kotto-misie-achtige wijze. Haar garde-robe is zeer beperkt, aan ijdelheden wordt luttel tijd besteed en arbeidzaam, met het kind in een doek op den rug gebonden, verricht zij al haar dagelijksche bezigheden.

Van de haardracht wordt iets meer werk gemaakt, omdat die waarschijnlijk, evenals bij de Togonnegers, in verband staat met bepaalde beteekenissen der in verschillende figuren gevlochten bundels, die op het eind soms worden omwonden met stukjes katoenlint. Voor het uitkammen dienen eigen gemaakte, bijna witte houten kammen van het taaie, z.g.n. parelhout.

De mannen houden echter het haar meermalen vrij kort (plaat $2 \mathrm{I}$ ), doch er is verschil in de kapsels van verschillende stammen. Meestal wordt het in talrijke vlechtjes gevlochten, die als horentjes in de hoogte steken, terwijl het stugge haar met karapa-olie wordt ingewreven om het wat soepeler te maken. Baard of knevel is geen boschnegermode, het aangezicht wordt steeds geschoren en zij zouden geen rasechte negers zijn, wanneer zij geen buitengewone zorg zouden wijden aan de schoonheid van het gebit.

Voor opschik stelt de boschnegervrouw bescheiden eischen : zij draagt zelfgehaakte enkelbanden, sepoen, die met witte aarde of pimba worden ingewreven, zooals ook onze dames hun linnen schoenen wit houden met gemalen krijt. Verder heeft zij voorliefde voor kettingen en armbanden van gekleurde, vooral roode kralen, een van ouds gezocht ruilmiddel bij alle negervolken; ook de door de Indianen vervaardigde halskettingen van cylindervormige avroe sierie, tapoe-tapoe en redi-boontje, zijn bij de boschneger-schoonen in trek, evenals ijzeren en houten vinger-, arm- en beenringen. Niet zeldzaam is het de vingers getooid te zien met een menigte koperen gordijnringen, terwij1 bij feestelijke gelegenheden een gekleurde zakdoek om den hals gebonden wordt en het haar wordt opgesmukt met gesneden houten pennen.

Ook de mannen vinden het noodig hun lichaam van versiersels te voorzien : de bovenarm is dikwijls omwonden door een of meer ijzeren ringen, evenals de polsen en de enkels ; bovendien worden halskettingen gedragen bestaande uit tanden van tijgers of andere dieren en die op een zelfde grootte zijn afgeslepen. 


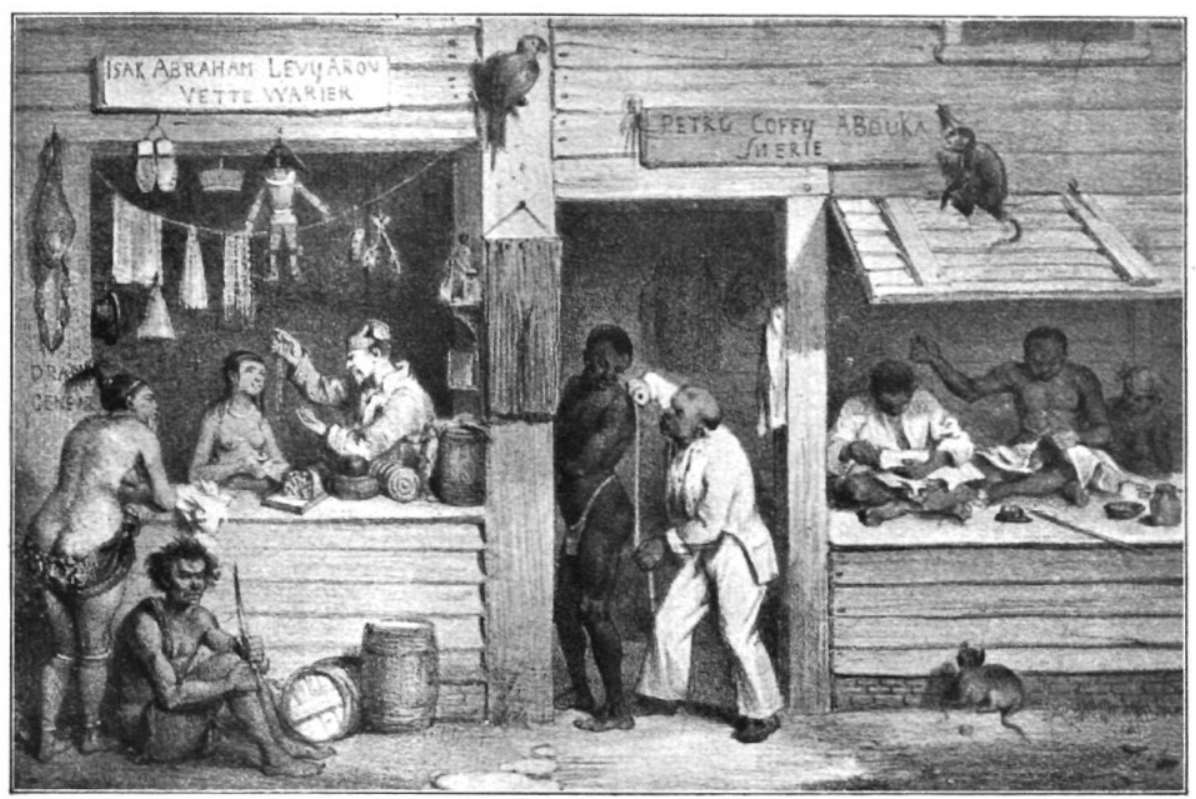

Plaat r6 (naar een teekening van P. J. Benoit).

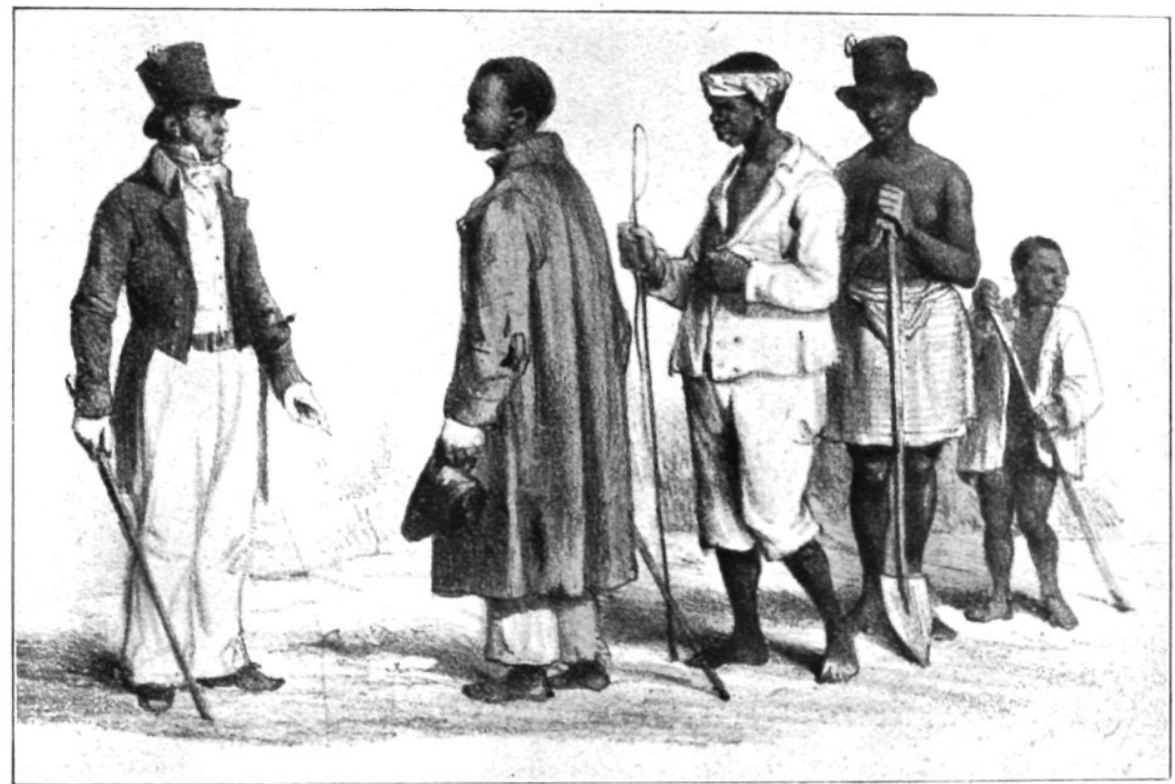

Plaat ${ }_{7} 7$ (naar een teekening van P. J. Benoit). 


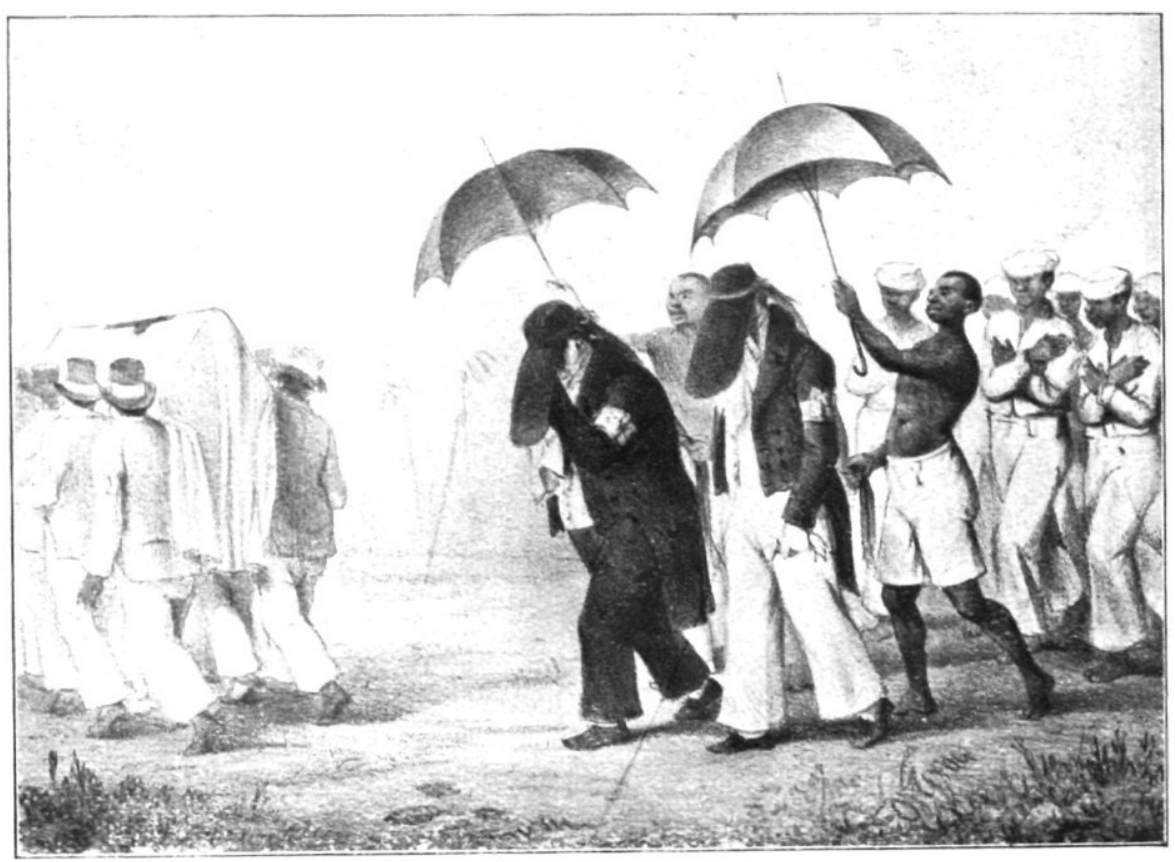

Plaat is (naar een teekening van P. J. Benoit).

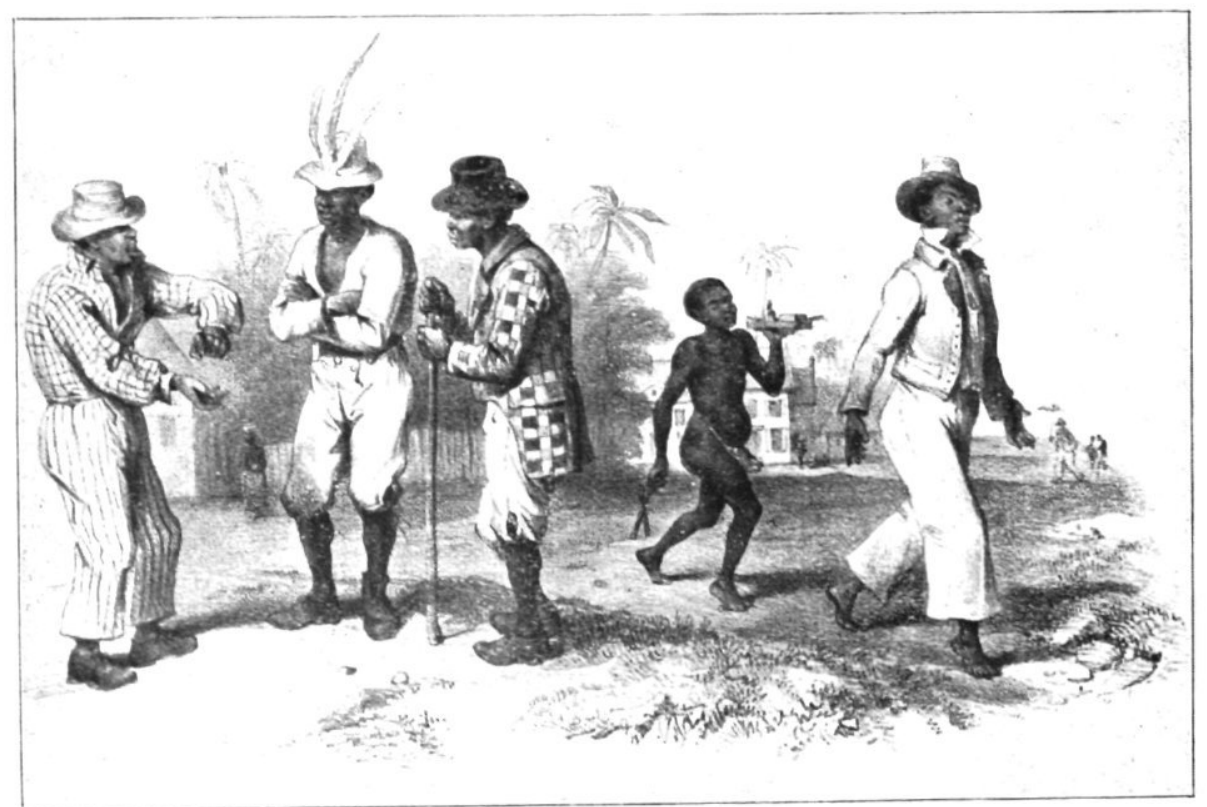

Plaat I9 (naar een teekenıng van P. J. Benoit). 


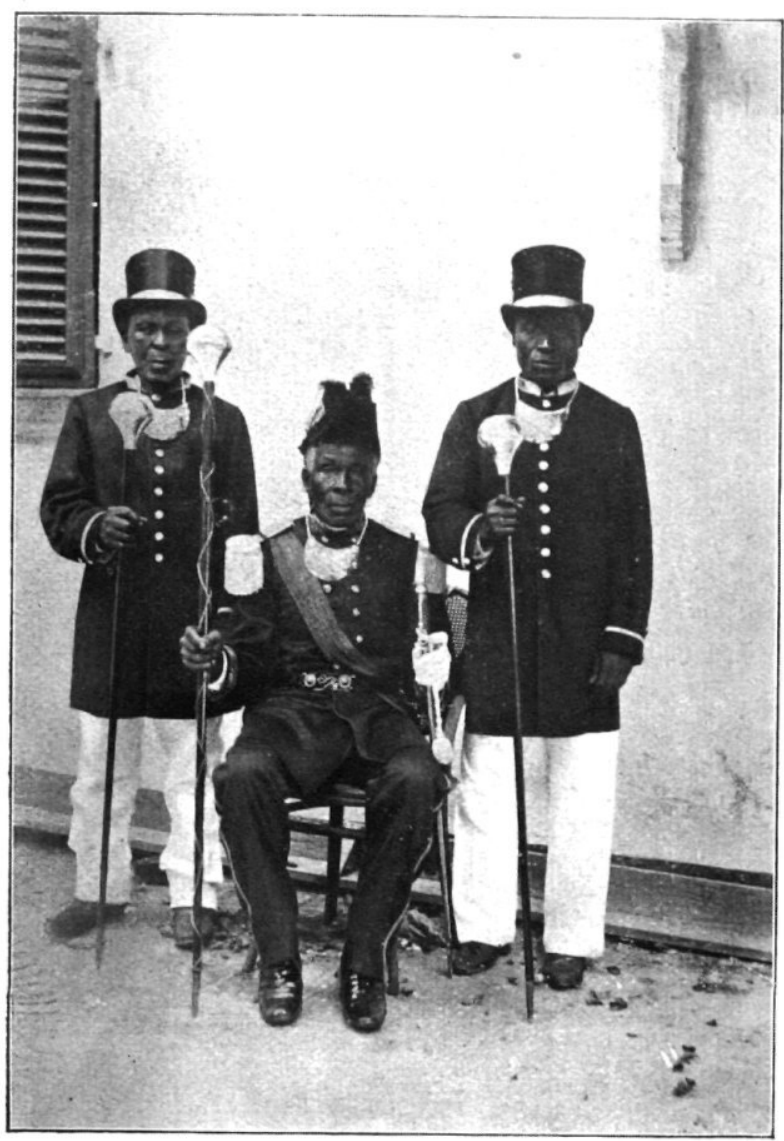

Plaat 20 lopname van den schrijver).

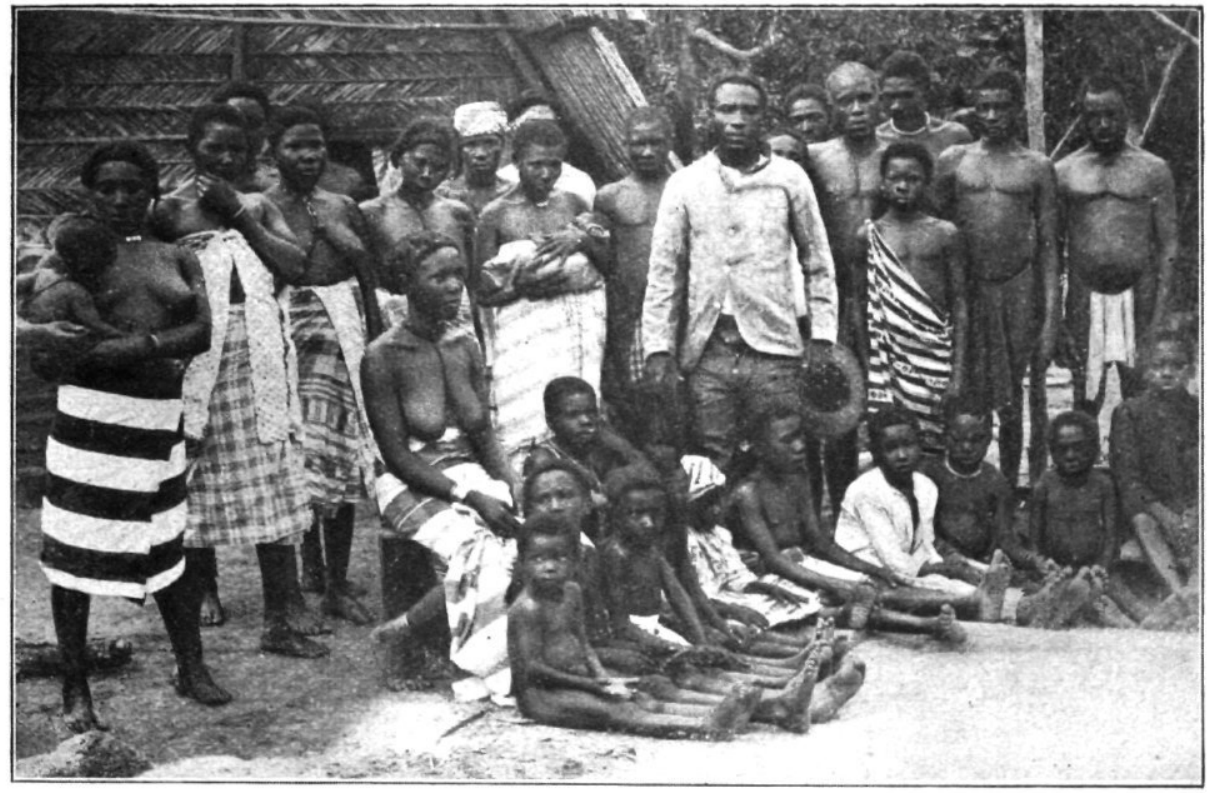




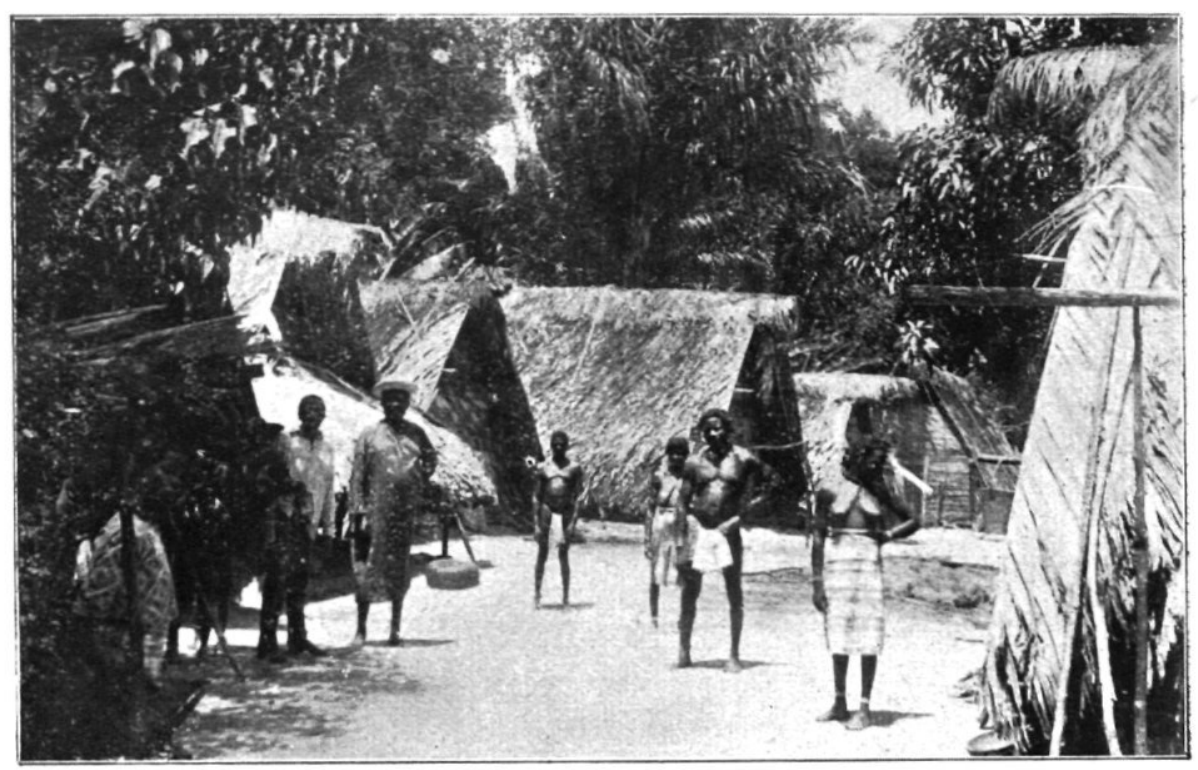

Plaat 22 (opname van den schrijver).

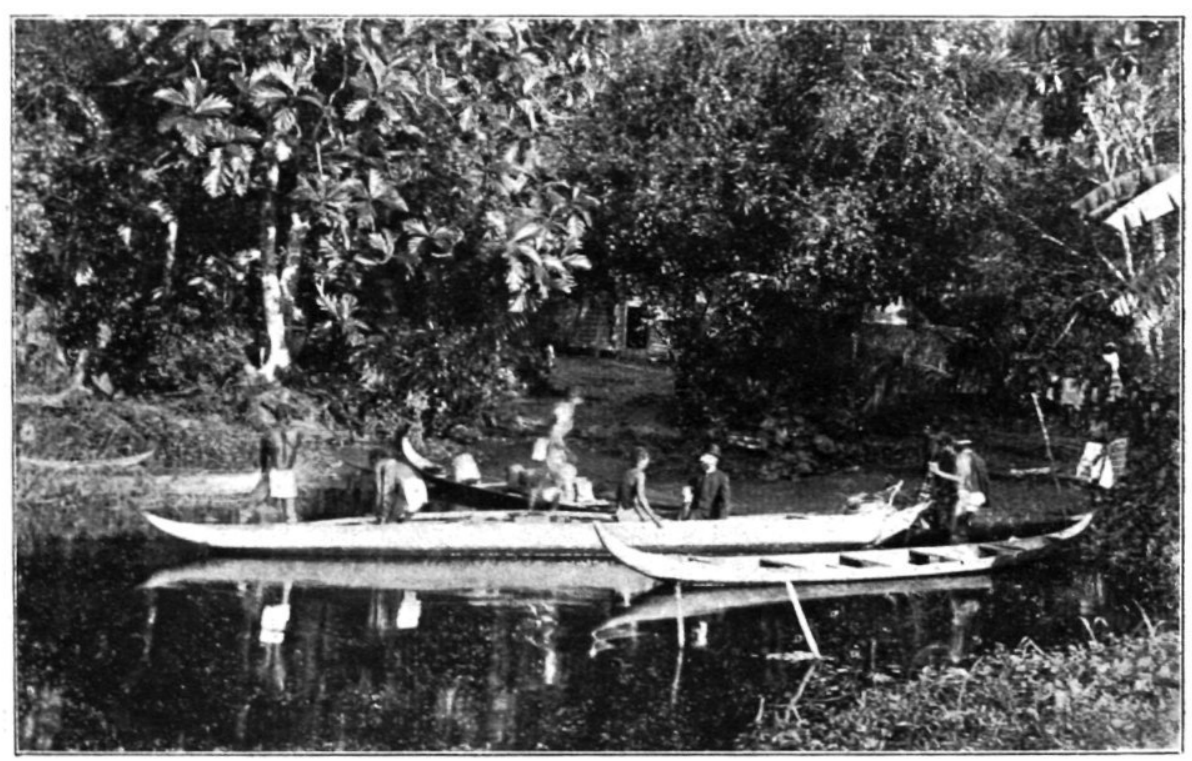

Plaat 23 (opname van den schrijver) 
Niet te verwarren met de versiersels, zijn de amuletten of obia's, waaraan zeer hooge waarde wordt gehecht, omdat die voorbehoedmiddelen zijn tegen booze geesten, tegen allerlei soort ongevallen en ook dienen als gelukaanbrengers van jacht en handel; daarom. worden ook aan hals en pooten van den jachthond obia's bevestigd. Tal van zaken worden door de loekoemans of zieners, die zich bezighouden met het bestaan der goden, daarvoor aangewezen. Als opperpriester van zijn stam had ook granman Oseisie het monopolie van verkoop van obia's, waarvan de hooge prijzen, met de levensbehoeften die hij als belasting hief, een goed deel uitmaakten van zijn inkomen.

Voor de samenstelling van obia's worden zeer veel gebruikt de katjesschelpen, die papa moni heeten, zoo genoemd naar het vroegere betaalmiddel der Papa-negers aan de kust van Dahomy. Enkele dezer blanke ornamentjes aan een koordje om den donkeren hals gedragen, hebben niet alleen' een sierend karakter maar behoeden de draagster voor heel wat onheil en schenken haar geluk in de liefde. Als wonderdadige obia's dienen verder uit katoen of katoenen draden gevormde cylindertjes en ringen, omregen met roode kralen en schelpjes, ook veeren van papegaaien, voelsprieten van kevers, glasscherfjes, stukjes hout, verder nagels, tanden en beentjes van tijgers en andere dieren. Hoe wonderlijker de samenvoeging, hoe sterker de werking is en de aan bandjes om hals, armen, ", pols, knieën of heupen gehangen voorwerpen, schenken het gemoed van den boschneger een zekere weldadige rust.

Als versieringsmiddel moet eveneens worden aangemerkt het voor een dansavond inwrijven van het lichaam met olie ; dit eischt de etiquette en de glimmend gemaakte huid doet dan denzelfden dienst als bij ons rok of smoking, zooals ook het zich besmeren met witte pimba bij godsdienstige ceremonies der Aucaners, wellicht overeen zal komen met het aantrekken door ons van een bizonder gewaad gedurende plechtige gelegenheden.

Ongetwijfeld moet ook als versiering van het lichaam, vooral bij mannen, vrouwen en kinderen, de tatouage worden gerekend, d.i. het insnijden van bepaalde figuren in de huid met een scherp mes en het daarna inwrijven der wond met houtskoolgruis en met arum-sap. Doordat de boschnegers hierbij geen kleurstof gebruiken, worden de lidteekens zwart. 't Is een zeer pijnlijke 
operatie die met een scheermes, soms zelfs met een glasscherf, door de vrouwen met een vaste hand wordt uitgevoerd. Behalve harceeringen, die worden aangebracht op het gelaat, de borst, den rug, de armen en de beenen, hebben de tatouage-figuren allerlei vormen, waarvan de beteekenis nog niet is uitgemaakt ; bovendien komen teekeningen voor uit het planten- of dierenrijk, b.v. de ananas, de wajé-figuur of staart van den adelaar, de schorpioen, enz. De explorateur De Goeje merkte op, dat bij de vrouwen de meeste tatouage-figuren zich bevinden onder haar paantje.

Vergroeit langzamerhand het lidteeken, dan wordt de operatie hernieuwd, doch ' $t$ is niet comme il faut om het lichaam overdadig te tatoueeren, evenals het bij den beschaafden mensch niet past om zich overdadig op te smukken. Bij de invoering der negerslaven uit Afrika bleek, dat alle stammen op een verschillende eigen manier getatoueerd waren.

Tijden een bezoek aan de stad, wat voor het zaken doen wel voorkomt, kleeden de boschnegers zich veelal in korte wambuizen van gekleurd katoen; broeken of schoenen worden niet gedragen. Op deze reizen worden zij dikwijls door de vrouwen vergezeld, wat echter in den slaventijd nooit gebeurde en waartoe zij eerst langzamerhand zijn overgegaan. Toen n.1. de Marrons zich tot stammen vereenigden, hadden zij geen vrouwen; deze werden later met groote moeite een voor een van de ondernemingen geschaakt en daarna zeer zorgvuldig verborgen gehouden. Om hen het ontvluchten te beletten, bond men vaak om hun middel een stevigen band, waaraan een groote bel en kleinere belletjes hingen. Ook om den hals werd soms een bellencollier gehangen en men was overtuigd dat dit voldoende was om het ontvluchten tegen te gaan.

Sterft een Boschneger, dan is o. a. een der gewoonten, dat hem een nieuwe witte jas wordt aangedaan en witte kralen in de ooren worden gestopt ; in de kist wordt dikwijls ook nog een kleedingstuk gelegd. Gedurende een jaar na den dood van den man, vader of moeder, dragen de vrouwen als rouwbetoon, een witte of blauwe doek om het hoofd en altijd een wit paantje; de mannen dragen een donkerkleurige kamisa, terwijl in den rouwtijd, zoowel door mannen als door vrouwen, de sieraden worden afgelegd.

(Wordt vervolgd) 